\title{
電線被覆材中微量 Cd の蛍光 X 線分析法による分析
}

\author{
山田隆* - 山田康治郎*·森山孝男*井上央*
}

\section{1.はじめに}

蛍光 X 線分析法 $(\mathrm{XRF})$ は，測定が迅速であることと試 料を非破壊で測定できること, また, 試料前処理が簡単で あるという特徵を持つことから，固体，液体の種々の材料 の組成分析に用いられており, 元素管理に重要な役割を果 たしている ${ }^{1,2)}$.

環境問題に対してもXRF は活用されており，工場排水， 河川水や大気粉塵の有害元素分析に成果を上げている 電気電子部品については, 廃電気電子リサイクル指令 （WEEE）および特定物質使用制限(RoHS) の法制化がな され，電線被覆材料の安定材として用いられる $\mathrm{Cd} や \mathrm{~Pb}$ の有害元素の分析が重要となっている.

XRF によって精度良く定量分析を行なうためには，マ トリックス効果を考慮に入れて分析する必要があるが，今 回, 電線被覆材中の微量 $\mathrm{Cd}$ 分析に対して, 試料調製に起 因する問題, 共存元素に対する補正方法の検討を行い, 正 確に分析を行う手法を求めたので紹介する.

\section{2. 試料前処理法}

原子吸光や ICP による材料の分析には, 溶液化した試 料が用いられる。 そのために湿式分解，高圧分解，マイク ロウェーブ分解によりプラスチック等の試料を分解し, 残 分の重金属を酸溶解して試料作成が行なわれる。この手法 では，プラスチック材料が異なると，酸の種類を変えるな ど，材料に応じた分解法を選択する必要がある。

蛍光 X 線分析では前処理を一切行なわずに, 固体試料 をそのまま測定することが可能である。電線材については, サンプルを数本並べてそのまま分析を行うことができる.

しかし, 電線被覆は様々な形状をしているので, 分析精度 を上げるためには, 試料の成型を行なってから, 蛍光 X 線分析に掛ける方が好ましい。

図 1 に蛍光 X 線分析用の 4 種類の前处理法を示す。そ れらは，1）電線を適当な長さに切断した後, 芯抜きをし て，そのまま試料セルに並べる．2）切断芯抜きをした材 料をホットプレスにてディスク状に成形する．3）切断芯

\footnotetext{
* Yamada, Takashi/Yamada, Yasujiro/

Moriyama, Takao/Inoue, Hisashi

理学電機工業(侏) 技術開発部

高㭇市赤大路町 14-8（５569-1146）

2004.5. 6 受理
}

抜きをした材料を凍結粉砕した後ホットプレスにて成形す る.4）切断芯抜きをした材料を凍結粉砕した後，保護膜 を貼った試料セルに充填する，の 4 つの方法である。高精 度分析を行なうためには，材料の加熱成形によるデイスク 化が必要であり，3）の処理が最も分析精度が良い。これ らのどの試料処理に押いても酸による分解は不要である.

\section{3 . 分析装置と測定条件}

蛍光 X 線分析では, 試料に 1 次 X 線を照射し, 試料中 各元素から発生する元素特有の特性 X 線を検出して試料 の組成分析を行なう。 $\mathrm{Cd}$ に対しては, $\mathrm{Cd}-\mathrm{K}$ 線を検出す ることで分析を行なう． $\mathrm{Cd}-\mathrm{K}$ 線を発生させるためには, 十分に高いエネルギーの 1 次 X 線を照射する必要がある。 そのためには, 1 次 X 線を発生させる X 線管のターゲッ 卜材には W または Mo が適するが，今回は汎用性の高い Mo 管を使用した。

$\mathrm{X}$ 線管電圧一電流は $60 \mathrm{kV}-50 \mathrm{~mA}$ とした。特性 X 線を 分光し, 検出する光学系には, $\operatorname{LiF}(200)$ の分光結晶とシ ンチレーションカウンター (SC) の検出器を使用した. 測 定線 $\mathrm{Cd}-\mathrm{K} \alpha$ に対する測定時間は，ピークに対して 100 秒, バックグラウンドに対して 50 秒で行なった. 後述する Mo -K $\alpha$-Compton 線の測定に対しては, 測定時間を 40 秒と した.

$\mathrm{Cd}-\mathrm{K} \alpha$ 線スペクトル部のバックグラウンドを低く押さ えるために Zr の一次フィルタ5) X 線管と試料の間に装 填した. また, 電線被服材によく含まれている難燃材の $\mathrm{Sb}$ のピークが $\mathrm{Cd}-\mathrm{K} \alpha$ 線の強度值に影響を及ぼさないように, $\mathrm{Sb}$ の重なり補正を行なった.

\section{Cdの分析}

\section{1 定量値に及ぼす共存元素の影響}

電線被覆には様々な元素が配合されている．標準試料と 未知試料とでマトリックスが異なると, カドミウムの X 線強度に影響を及ぼす。定量精度を上げるためには, 共存 元素補正を行なえばよいが，その場合には，分析には直接 必要のない共存元素の測定も行わ杖ならず，それら元素 を含有した標準物質の準備も必要となる.

この煩雑さを避ける方法として，コンプトン強度やバッ クグラウンド強度をモニタする散乱線内標準法 ${ }^{6}$ がある. この方法では, 他の共存元素を測定する必要が無く, 簡便 な分析が行なえる. 以下に, 散乱線補正法を説明する. 


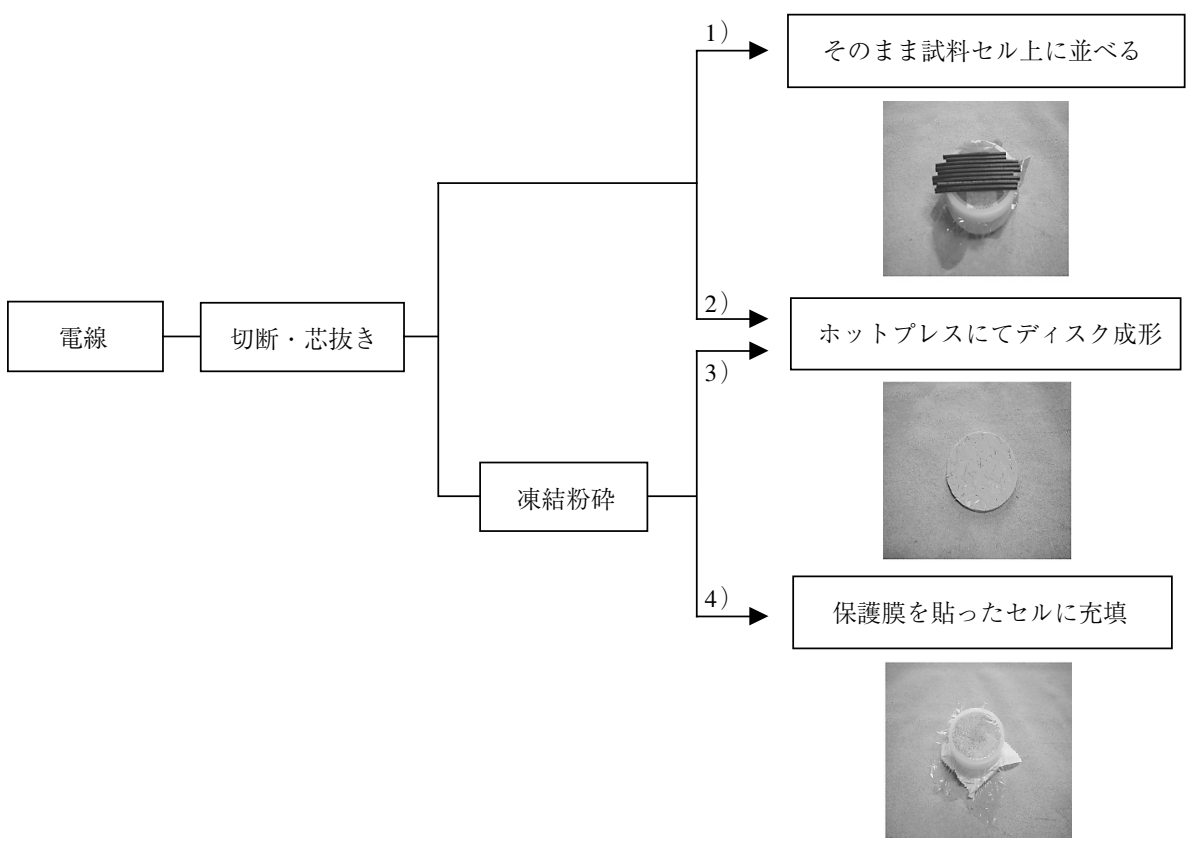

図 1 蛍光 $X$ 線分析用試料処理法

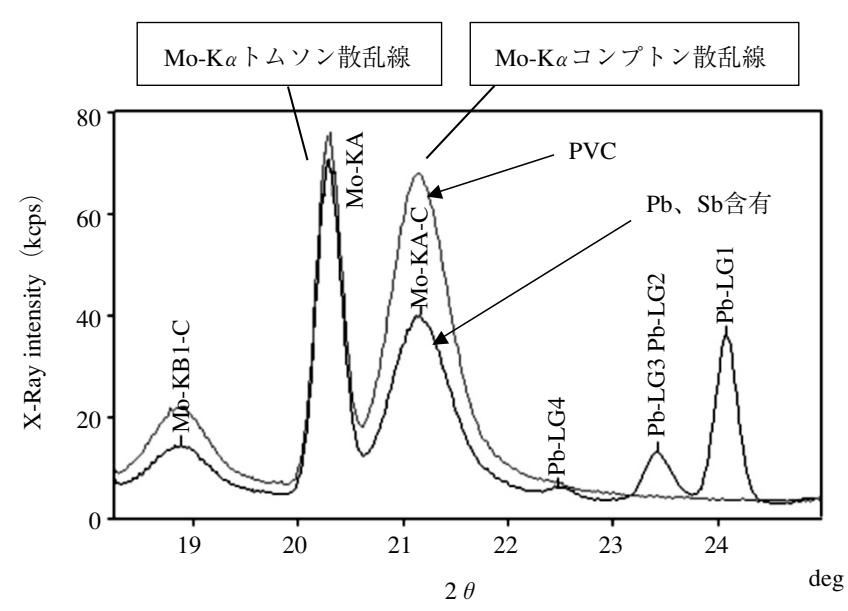

図 2 PbtoSb を含む PVC 試料と含まないPVC 試料との Mo-K $\alpha$ コンプトン散乱線強度の比較

\section{2 コンプトン散乱線強度および $\mathrm{Cd}-\mathrm{K} \alpha$ バックグラ ウンド強度}

コンプトン散乱線強度およびバックグラウンド強度と質 量吸収係数の間には良好な相関関係があることが一般的に
知られており，質量吸収係数からマトリックスの影響を補 正をすることができる。この手法は岩石分析での $\mathrm{Rb}, \mathrm{Sr}$ 等の微量成分の分析によく用いられている7 . コンプトン 線波長と分析線波長の間に他の元素の吸収端が存在した場 合，その相関関係が崩れるが，今回の試料においては $\mathrm{Mo}^{-}$ $\mathrm{K} \alpha$ コンプトン散乱線波長と $\mathrm{Cd}-\mathrm{K} \alpha$ の波長の間には他の 含有元素の吸収端がないことから，この手法を用いること ができる。

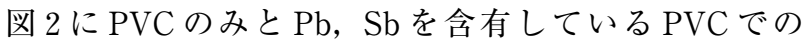
$\mathrm{Mo}-\mathrm{K} \alpha$ コンプトン散乱線付近のチャートを示す. Mo-KA $(\alpha)-\mathrm{C}$ と表記された幅広いピークが $\mathrm{Mo}-\mathrm{KA}(\alpha)$ コンプ トン散乱線である. $\mathrm{Pb}, \mathrm{Sb}$ を含む試料では, $\mathrm{Mo}-\mathrm{K} \alpha$ コ ンプトン散乱線が低くなっていることがわかる．これら， コンプトン散乱線またはバックグラウンド強度を内標準と して検量線を補正する。

図 3 に $\mathrm{Cd}$ 含有 $\mathrm{PVC}$ 試料と $\mathrm{Cd}, \mathrm{Pb}$ 含有 $\mathrm{PVC}$ 試料を用 いた $\mathrm{Cd}$ 検量線を示す。図 $3 \mathrm{a} ）$ は $\mathrm{Cd}-\mathrm{K} \alpha$ ネット強度を 用いた検量線，図 3 b）は $\mathrm{Cd}-\mathrm{K} \alpha$ ネット強度と内標準と して Mo-K $\alpha$ コンプトン散乱線強度を用いた検量線, 図 3 c）は $\mathrm{Cd}-\mathrm{K} \alpha$ ネット強度と内標準として $\mathrm{Cd}-\mathrm{K} \alpha$ のバッ
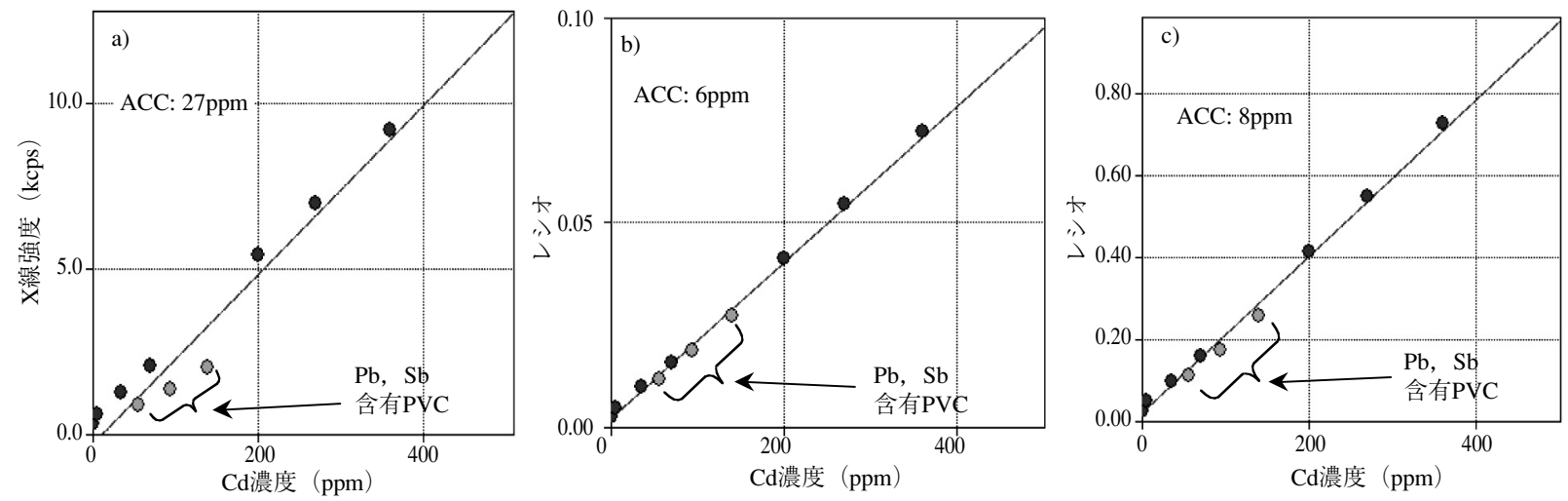

図 $3 \mathrm{Cd}$ 検量線の比較；a）Cd-K $\alpha$ 線強度のみを使用，b）Mo-K $\alpha$ コンプトン散乱線を内標準として補正，c） $\mathrm{Cd}-\mathrm{K} \alpha$ 線バックグラウンドを内標準として補正 

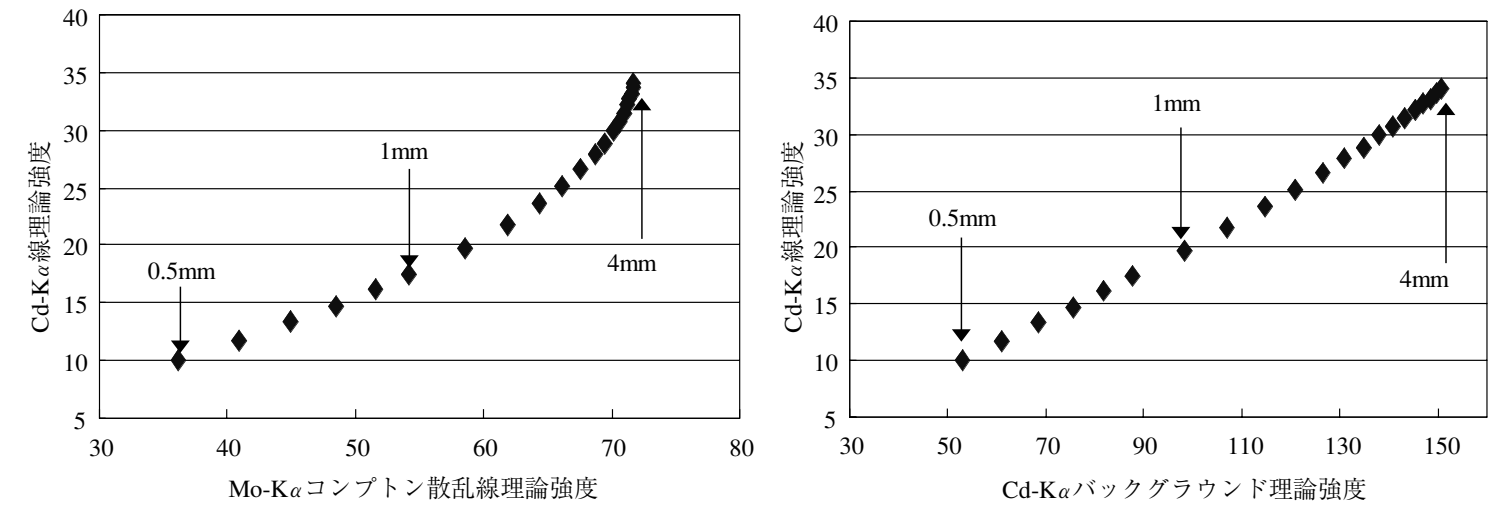

図 $4 \mathrm{Cd}-\mathrm{K} \alpha$ 線理論強度と Mo-K $\alpha$ コンプトン散乱線理論強度の相関（左図）および $\mathrm{Cd}-\mathrm{K} \alpha$ 線理論 強度と $\mathrm{Cd}-\mathrm{K} \alpha$ 線バックグラウンド理論強度の相関（右図）

クグラウンド強度を用いた検量線を示す。

a) で示されるように, $\mathrm{Cd}$ 含有 $\mathrm{PVC}$ 試料と $\mathrm{Cd}, \mathrm{Pb}$ 含 有 PVC 試料とでは，検量線がそれぞれ別になる，b）の $\mathrm{Mo}-\mathrm{K} \alpha$ コンプトン散乱線強度を内標準として用いた場合 では，両試料とも 1 本の検量線に乗る。c）のバックグラ ウンドを内標準とした場合でも，b）と同様に 1 本の検量 線に乗ることがわかる.

\section{$4.1 \mathrm{Cd}-\mathrm{K} \alpha$ 分析に及ぼす試料厚みの影響}

$\mathrm{Cd}-\mathrm{K} \alpha$ 線のエネルギーは $23 \mathrm{keV}$ と高く, 電線被覆材 のような主に軽い元素で構成される材料は容易に透過する. また，コンプトン散乱線強度や $\mathrm{Cd}-\mathrm{K} \alpha$ バックグラウンド 強度も試料厚さによって増大する. したがって, 試料ごと に厚さが変わる試料を扱う場合には，厚さの効果を考慮す る必要がある。ここで，シート厚さが変化した時のシミュ レーション計算を行ない, $\mathrm{Cd}-\mathrm{K} \alpha$ 線理論強度と $\mathrm{Mo}^{-} \mathrm{K} \alpha$ コンプトン散乱線理論強度及び $\mathrm{Cd}-\mathrm{K} \alpha$ 線バックグラウン ド理論強度の関係を計算した. 理学製の装置にはファンダ メンタルパラメータ法 ${ }^{8)}$ (FP 法) を実行する演算機能が 搭載されており，この演算機能を用いて，シミュレーショ ン計算を行なうことができる. 図 4 にそれぞれの演算結果 を示した. 左図の $\mathrm{Cd}-\mathrm{K} \alpha$ 線とコンプトン散乱線の相関図 からは，試料厚さが厚くなるにつれコンプトン散乱線強度 の強度増加率は $\mathrm{Cd}-\mathrm{K} \alpha$ 線強度の伸びに対して鈍いことが わかる. 一方, 右図の $\mathrm{Cd}-\mathrm{K} \alpha$ 線と $\mathrm{Cd}-\mathrm{K} \alpha$ 線バックグラ ウンドの相関図からは，厚さが増しても双方とも増加を続 け，比例関係を保つことがわかる。これらの結果を見ると， 試料厚みの影響を受けにくくするためには，コンプトン散 乱線よりも $\mathrm{Cd}-\mathrm{K} \alpha$ バックグラウンドを内標準として用い たほうが良いことがわかる。

図 5 に $2 \mathrm{~mm}$ 厚の $\mathrm{Cd}$ 含有 $\mathrm{PVC}$ 試料を用いて基準検量 線を作成し，0.5，1.0，1.5，2.0 mm 厚と厚さの異なる 試料を測定した。厚さの異なる試料は $2200 \mathrm{ppm} の \mathrm{Cd}$ を 含む. 図 $5 \mathrm{a}$ ）は $\mathrm{Mo}-\mathrm{K} \alpha$ コンプトン散乱線強度を内標準 とした場合を，b）は $\mathrm{Cd}-\mathrm{K} \alpha$ 線バックグラウンド強度を 内標準とした場合を示す．FP 法でのシミュレーション結 果通り，厚さの異なる試料を測定する場合には，コンプト ン散乱線よりも $\mathrm{Cd}-\mathrm{K} \alpha$ バックグラウンドを内標準とする 方が，厚さの補正の効果が優れていることがわかる.
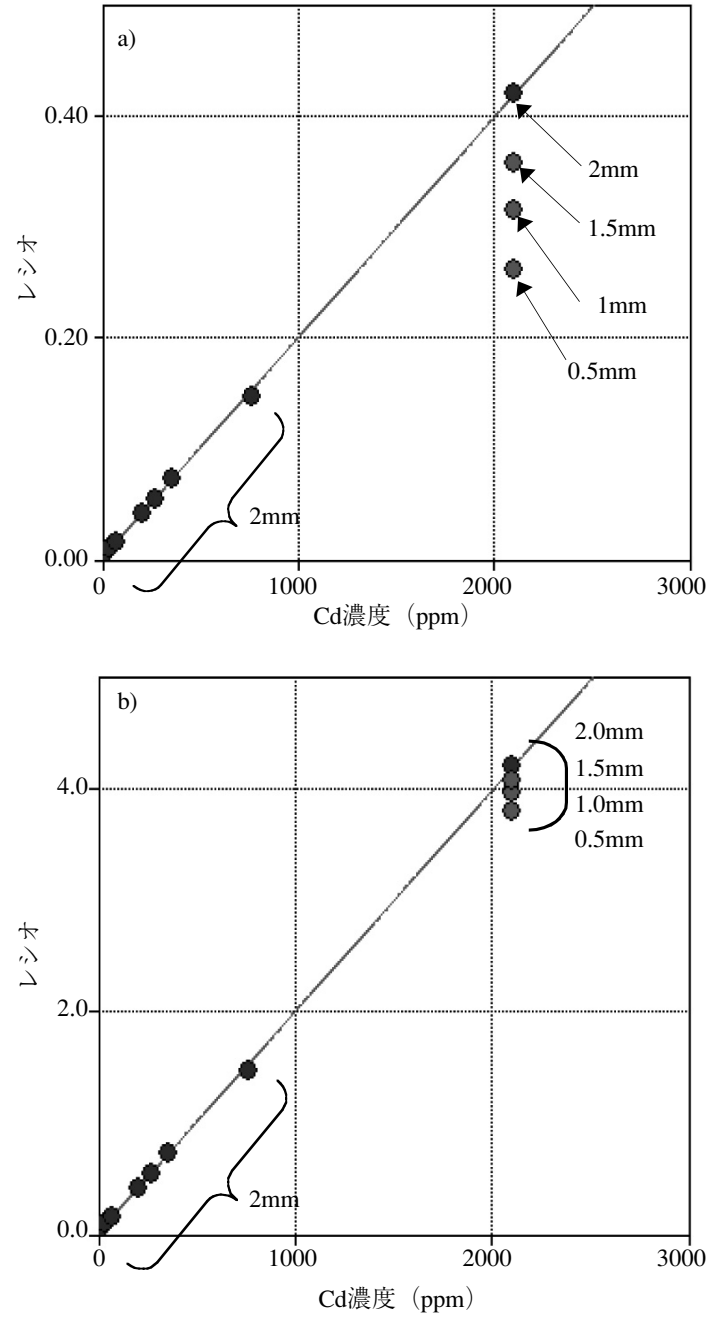

図 5 種々の厚さの試料に対する Cd の検量線；a） $\mathrm{Mo}^{-}$ K $\alpha$ コンプトン散乱線を内標準として補正. b) Cd -K $\alpha$ 線バックグラウンドを内標準として補正

\subsection{FP 法による分析}

FP 法においては今回のような電線被覆材試料に対して は薄膜モデルにて演算を行なって分析值を求める。この手 法では, 共存元素補正とともに厚みの補正も同時に行うこ とができるので，場合によっては検量線法よりも正確な分 析が可能である. $\mathrm{Cd}-\mathrm{K} \alpha$ 線測定強度と FP 法計算による 


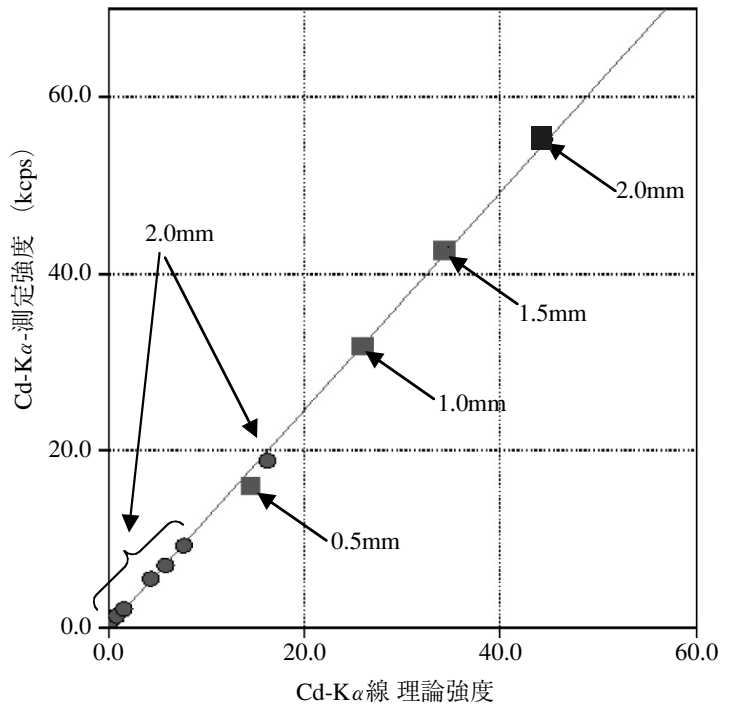

図 $6 \mathrm{FP}$ 法を用いて求めた $\mathrm{Cd}-\mathrm{K} \alpha$ 感度較正図

理論 $\mathrm{X}$ 線強度の相関を図 6 に示す。黒丸は試料厚さが $2 \mathrm{~mm}$ の Cd 濃度の異なる試料であり, 黒四角は濃度一定 で厚さの異なる試料である。試料の厚さが異なっても，良 好な相関が得られている.

\section{5. をと め}

電線被覆材中の $\mathrm{Cd}$ 分析に対して, バックグラウンドを 内標準として補正する方法と FP 法の両者を紹介した。試
料厚さの補正を不要とするためには，X 線に対して無限厚 さになるように試料を重ねるなどの措置をとればよいが， そのように出来ない場合も多い，その場合には試料厚みを なるべく一定にしてバックグラウンドを用いた内標準法を 用いることが望ましい. マトリックスの異なる種々の材料 を扱う場合には，厚さの情報を加味した FP 法は検量線法 よりも正確な分析ができる。しかし，FP 法を用いるため には, 分析対象元素以外の主要元素も測定する必要があり, 検量線法よりは時間がかかる. 迅速な分析には検量線法が 向いており, 今回, 本解説では, 検量線法の説明を主に行っ た. 迅速性と分析要求レベルに応じて適切な分析手法を選 択して分析を行なうことが必要である.

1) JIS R 2216 (1995)

参 考 文 献

2) JIS G 1254 (1972)

3 ）土器屋由紀子 : X 線分析の進歩，15，89（1984）

4) 田中英樹：X 線分析の進歩，16，9（1985）

5 ）岡下英樹：X 線分析の進歩，8，105（1976）

6 ）大野勝美他: “X 線分析法” (1987), 共立出版

7 ) Ahmedali, S. T. : X-RAY FLUORESCENCE ANALYSIS in the GEOLOGICAL SCIENCES, Advances in Methodology, Geological Association of Canada, Montreal, Quebee (1989)

8 ）河野久征：X 線分析の進歩，19，307（1988） 